\title{
Social, demographic and clinical characteristics of patients suffering from peripheral vascular disease treated surgically compared to patients treated with endovascular angioplasty
}

\author{
Renata Piotrkowska1 ${ }^{1}$, Marek Dobosz ${ }^{1}$, Janina Książek ${ }^{1}$, Grzegorz Halena²
}

\author{
${ }^{1}$ Department of Surgical Nursing, Faculty of Health Sciences, Medical University \\ of Gdansk, Gdansk, Poland \\ ${ }^{2}$ Clinic of Cardiac and Vascular Surgery, Faculty of Medicine, Medical University \\ of Gdansk, Gdansk, Poland
}

Submitted: 6 April 2017

Accepted: 10 June 2017

Arch Med Sci Atheroscler Dis 2017; 2: e9-e15

DOI: https://doi.org/10.5114/amsad.2017.68539

Copyright (c) 2017 Termedia \& Banach

\section{Abstract}

Introduction: Atherosclerosis is the most common cause of chronic lower limb ischaemia. Many factors that have a crucial influence on the development of the disease, its course and prognosis have been identified. The risk factors seem to be subject to interventions due to their susceptibility to changes. It is important to increase the engagement of doctors and nurses performing the screening oriented on risk factors, medical consultation regarding giving up smoking, changing the diet and undertaking physical activity. Therefore, knowledge of the patients' health situation allows introduction of optimal treatment in this group of patients.

Material and methods: The study group consisted of 119 patients with peripheral artery atherosclerosis, who underwent surgical and endovascular repair. The diagnostic survey method was used in this study. The socio-demographic and clinical data were collected using an originally developed questionnaire. The statistical analysis was performed using the data analysis software system Statistica, version 10.0, by StatSoft Inc. (2011) and an Excel spreadsheet. The statistical significance was set at $p<0.05$ for all calculations.

Results: There were statistically significant differences between the analysed groups with regard to severity of ischaemia $(p=0.0001)$, intermittent claudication $(p=0.0001)$, rest pain $(p=0.0001)$, ulceration $(p=0.0031)$, smoking $(p=0.0075)$ and comorbidities (percutaneous coronary interventions $p=0.0299$; ischaemic stroke $p=0.0235$ ).

Conclusions: There are significantly more patients with more advanced disease and ex-smokers in the surgically treated group. There are significantly more patients with a history of ischaemic stroke, surgical coronary interventions and current smokers in the endovascular group.

Key words: risk factors, surgical treatment, endovascular angioplasty, health situation, peripheral artery atherosclerosis.

\section{Introduction}

Atherosclerosis is the most common cause of chronic lower limb ischaemia [1-3]. The ailments specific for chronic limb ischaemia are intermittent claudication, rest pain and tissue necrosis [4]. The disease itself

\author{
Corresponding author: \\ Renata Piotrkowska \\ Department of \\ Surgical Nursing \\ Faculty of Health Sciences \\ Medical University \\ of Gdansk \\ 7 Dębinki St \\ 80-227 Gdansk, Poland \\ Phone: +48 583491247 \\ E-mail: rpiotrkowska@ \\ gumed.edu.pl
}


is of chronic nature and requires long-term treatment [1-5]. There are two basic classifications used to assess the severity of limb ischaemia: the Fontaine classification and Rutherford classification. Both allow one to assess the progression of the disease and treatment outcome $[2,6]$.

Many factors that have a crucial influence on the development of the disease, its course and prognosis have been identified $[1-5,7,8]$. They include advanced age, male sex, diabetes, arterial hypertension, smoking, hyperlipidaemia and low physical activity $[1-5,7,8]$. Current recommendations issued by the American College of Cardiology and American Heart Association (ACC/AHA) and developed based on the results of clinical trials concerning secondary prevention in patients with diagnosed lower limb atherosclerosis describe patients with peripheral artery disease (PAD) as a high-risk population, which requires intensive modification of risk factors $[8,9]$.

The therapy of chronic lower limb ischaemia requires an interdisciplinary approach, which includes medical, educational and psychological interventions. The invasive treatment modalities include mainly vascular bypass surgery, percutaneous transluminal angioplasty (PTA) and hybrid procedures, which integrate both former techniques [10-17].

\section{Aim}

The objective of this study is to compare the social, demographic and clinical characteristics of patients suffering from peripheral vascular disease treated surgically against patients treated with endovascular angioplasty.

\section{Material and methods}

The study group consisted of 119 patients treated in the Clinic of Cardiac and Vascular Surgery, University Clinical Centre in Gdansk, Poland, for peripheral artery atherosclerosis. Vascular bypass surgery was performed in 59 patients, whereas 60 had endovascular angioplasty performed. All of the patients participated in the study on a voluntary basis and had their anonymity preserved. The project of the study was approved by the Independent Bioethical Committee for Research, established by the Medical University of Gdansk, Poland.

The diagnostic survey method was used in this study. The socio-demographic and clinical data were collected using an originally developed questionnaire.

\section{Statistical analysis}

The entire statistical analysis was performed using the data analysis software system Statisti- ca, version 10.0, by StatSoft. Inc. (2011) and an Excel spreadsheet. The statistical significance was set at the level of $p<0.05$ for all calculations.

\section{Results}

The first group (treated surgically) consisted of $42(71.2 \%)$ men and 17 women $(28.8 \%)$, whereas there were 38 (63.3\%) men and 22 (36.7\%) women in the endovascular group. The mean age of surgically treated patients was $63.8 \pm 8.8$ years (range: $47-81$ years, median: 63 years), and 63.7 \pm 7.5 years (range: $46-76$ years, median: 63 years) in the endovascular group. Most of the patients, both in the surgical and endovascular group, had completed primary (74.6\%) and vocational (55.0\%) education, and received a retirement pension $(81.3 \%)$ or disability benefits $(86.7 \%)$. Most subjects in both groups were married (74.7\%).

There was no difference between the analysed groups with regard to age $(p=0.9486)$, gender $(p=0.3615)$, education level $(p=0.0680)$, marital status $(p=0.3368)$ or source of income ( $p=$ 0.6423).

Statistically significant differences between the groups were observed for ischaemia stage, intermittent claudication, rest pain and ulcerations. More advanced lower limb ischaemia, rest pain and foot ulcerations were observed significantly more frequently in the group of patients qualified for surgical treatment than in the endovascular group. Intermittent claudication on the other hand was observed more frequently in patients undergoing endovascular angioplasty (Table I).

Mean duration of the symptoms of chronic lower limb ischaemia was $5.9 \pm 5.3$ years (range: 1-20 years, median: 4 years) in the surgical group and $5.0 \pm 3.6$ years (range: 1-15 years, median: 4 years) in the endovascular one. No statistically significant differences in terms of the duration of chronic lower limb ischaemia symptoms were observed in the analysed groups (Table II).

There were significantly more current tobacco smokers in the endovascular group and ex-smokers in the surgically treated group. Maximum duration of smoking in the surgical and endovascular groups was 50 and 60 years, respectively. The mean number of cigarettes smoked daily in the surgical (18.8 \pm 18.7 cigarettes, range: 0-102 cigarettes, median: 20 cigarettes) and endovascular (19.9 \pm 17.8 cigarettes, range: 0-103 cigarettes, median: 20 cigarettes) groups was similar (Table III).

The body mass index (BMI) was used to describe the body mass of the examined subjects. Mean BMI in the surgical group was $26.1 \pm 4.7$ (range: 17.2-35.9, median: 25.0), and $27.7 \pm 6.0$ (range: $16.8-57.4$, median: 27.1 ) in the endovascular one. The mean BMI values in both groups indicated overweight. The statistical analysis did 
Table I. Clinical symptoms according to the Fontaine classification in both study subgroups

\begin{tabular}{|c|c|c|c|}
\hline Parameter & $\begin{array}{l}\text { Surgical treatment } \\
\qquad(n=59)\end{array}$ & $\begin{array}{l}\text { Endovascular angioplasty } \\
\qquad(n=60)\end{array}$ & $P$-value \\
\hline \multicolumn{4}{|c|}{ Ischaemia stage: } \\
\hline II & $0(0.0 \%)$ & $27(45.0 \%)$ & \multirow{3}{*}{$\begin{array}{l}\chi^{2}=38.94 \\
p=0.0001\end{array}$} \\
\hline III & 25 (42.4\%) & $22(36.7 \%)$ & \\
\hline IV & $34(57.6 \%)$ & $11(18.3 \%)$ & \\
\hline \multirow[t]{2}{*}{ Claudication } & \multirow[t]{2}{*}{$0(0.0 \%)$} & \multirow[t]{2}{*}{$27(45.0 \%)$} & $\chi^{2}=34.34$ \\
\hline & & & $p=0.0001$ \\
\hline \multirow[t]{2}{*}{ Rest pain } & \multirow[t]{2}{*}{$59(100.0 \%)$} & \multirow[t]{2}{*}{$33(55.0 \%)$} & $\chi^{2}=34.34$ \\
\hline & & & $p=0.0001$ \\
\hline \multirow[t]{2}{*}{ Ulceration } & \multirow[t]{2}{*}{$28(47.5 \%)$} & \multirow[t]{2}{*}{$13(21.7 \%)$} & $\chi^{2}=8.76$ \\
\hline & & & $p=0.0031$ \\
\hline \multirow[t]{2}{*}{ Small necrosis } & \multirow[t]{2}{*}{7 (11.9\%) } & \multirow[t]{2}{*}{$2(3.3 \%)$} & $\chi^{2}=3.10$ \\
\hline & & & $p=0.0784$ \\
\hline
\end{tabular}

Table II. Duration of symptoms of chronic lower limb ischaemia in the studied population

\begin{tabular}{|lccc|}
\hline $\begin{array}{l}\text { Duration of symptoms } \\
\text { of chronic lower limb ischaemia }\end{array}$ & $\begin{array}{c}\text { Surgical treatment } \\
(n=59)\end{array}$ & $\begin{array}{c}\text { Endovascular angioplasty } \\
(n=60)\end{array}$ & $P$-value \\
\hline Mean \pm SD & $5.9 \pm 5.3$ & $5.0 \pm 3.6$ & $Z=0.39$ \\
\hline Range & $1.0-20.0$ & $1.0-15.0$ & $p=0.6941$ \\
\hline Median & 4.0 & 4.0 & \\
\hline $95 \% \mathrm{Cl}$ & $4.5 ; 7.3$ & $4.0 ; 5.9$ & \\
\hline
\end{tabular}

Table III. Patients' characteristics with regard to tobacco smoking

\begin{tabular}{|c|c|c|c|}
\hline Parameter & $\begin{array}{l}\text { Surgical treatment } \\
\qquad(n=59)\end{array}$ & $\begin{array}{l}\text { Endovascular angioplasty } \\
\qquad(n=60)\end{array}$ & $P$-value \\
\hline \multicolumn{4}{|c|}{ Number of cigarettes smoked per day: } \\
\hline Mean \pm SD & $18.8 \pm 18.7$ & $19.9 \pm 17.8$ & \multirow{4}{*}{$\begin{array}{c}Z=-0.90 \\
p=0.3677\end{array}$} \\
\hline Range & $0.0-102.0$ & $0.0-103.0$ & \\
\hline Median & 20.0 & 20.0 & \\
\hline $95 \% \mathrm{Cl}$ & $14.0 ; 23.7$ & $15.3 ; 24.5$ & \\
\hline \multicolumn{4}{|l|}{ Duration of smoking [years]: } \\
\hline Mean \pm SD & $28.7 \pm 14.8$ & $30.5 \pm 15.4$ & \multirow{4}{*}{$\begin{array}{c}Z=-0.74 \\
p=0.4584\end{array}$} \\
\hline Range & $0.0-50.0$ & $0.0-60.0$ & \\
\hline Median & 30.0 & 33.0 & \\
\hline $95 \% \mathrm{Cl}$ & $24.8 ; 32.6$ & $26.5 ; 34.4$ & \\
\hline \multirow[t]{2}{*}{ Current tobacco smokers } & \multirow[t]{2}{*}{$20(33.9 \%)$} & \multirow[t]{2}{*}{$35(58.3 \%)$} & $\chi^{2}=7.15$ \\
\hline & & & $p=0.0075$ \\
\hline \multirow[t]{2}{*}{ Ex-tobacco smokers } & \multirow[t]{2}{*}{$30(50.8 \%)$} & \multirow[t]{2}{*}{$19(31.7 \%)$} & $\chi^{2}=4.52$ \\
\hline & & & $p=0.0335$ \\
\hline \multirow[t]{2}{*}{ Non-smokers } & \multirow[t]{2}{*}{$9(15.3 \%)$} & \multirow[t]{2}{*}{$6(10.0 \%)$} & $\chi^{2}=0.75$ \\
\hline & & & $p=0.3879$ \\
\hline
\end{tabular}


not reveal any difference between the groups in terms of BMI (Table IV).

The comprehensive characteristics of both study subgroups in relation to the presence of comorbidities are presented in Table V.
The most common comorbidity in the surgical group was arterial hypertension (41 subjects, $69.5 \%$ ), followed by diabetes ( 23 subjects, $39.0 \%$ ), ischaemic heart disease (19 subjects, $32.2 \%$ ) and myocardial infarct (12 subjects, 20.3\%). The most

Table IV. Body mass index values in the studied population

\begin{tabular}{|lccc|}
\hline BMI & $\begin{array}{c}\text { Surgical treatment } \\
(n=59)\end{array}$ & $\begin{array}{c}\text { Endovascular angioplasty } \\
(n=60)\end{array}$ & $P$-value \\
\hline Mean \pm SD & $26.1 \pm 4.7$ & $27.7 \pm 6.0$ & $Z=-1.84$ \\
Range & $17.2-35.9$ & $16.8-57.4$ & \\
\hline Median & 25.0 & 27.1 & \\
\hline $95 \% \mathrm{Cl}$ & $24.8 ; 27.3$ & $26.1 ; 29.2$ & \\
\hline
\end{tabular}

Table V. Comorbidities in the studied population

\begin{tabular}{|c|c|c|c|}
\hline Parameter & $\begin{array}{l}\text { Surgical treatment } \\
\qquad(n=59)\end{array}$ & $\begin{array}{l}\text { Endovascular angioplasty } \\
\qquad(n=60)\end{array}$ & $P$-value \\
\hline \multirow[t]{2}{*}{ Ischaemic stroke } & $0(0.0 \%)$ & $5(8.3 \%)$ & $\chi^{2}=5.13$ \\
\hline & & & $p=0.0235$ \\
\hline \multirow[t]{2}{*}{ TEA ICA } & $5(8.5 \%)$ & $4(6.7 \%)$ & $\chi^{2}=0.14$ \\
\hline & & & $p=0.7092$ \\
\hline \multirow[t]{2}{*}{$\mathrm{PCl}$} & $1(1.7 \%)$ & $7(11.7 \%)$ & $\chi^{2}=4.72$ \\
\hline & & & $p=0.0299$ \\
\hline \multirow[t]{2}{*}{ CABG } & $9(15.3 \%)$ & $7(11.7 \%)$ & $\chi^{2}=0.33$ \\
\hline & & & $p=0.5663$ \\
\hline \multirow[t]{2}{*}{ Atrial fibrillation } & $2(3.4 \%)$ & $0(0.0 \%)$ & $\chi^{2}=2.07$ \\
\hline & & & $p=0.1504$ \\
\hline \multirow[t]{2}{*}{ Ischaemic heart disease } & $19(32.2 \%)$ & $16(26.7 \%)$ & $\chi^{2}=0.44$ \\
\hline & & & $p=0.5075$ \\
\hline \multirow[t]{2}{*}{ Myocardial infarct } & $12(20.3 \%)$ & $18(30.0 \%)$ & $\chi^{2}=1.47$ \\
\hline & & & $p=0.2249$ \\
\hline \multirow{2}{*}{$\begin{array}{l}\text { History of surgery due } \\
\text { to AAA }\end{array}$} & 2 (3.4\%) & $0(0.0 \%)$ & $\chi^{2}=2.07$ \\
\hline & & & $p=0.0769$ \\
\hline \multirow[t]{2}{*}{ Renal failure } & $1(1.7 \%)$ & $1(1.7 \%)$ & $\chi^{2}=0.01$ \\
\hline & & & $p=0.9904$ \\
\hline \multirow[t]{2}{*}{ Dialysis } & $0(0.0 \%)$ & $1(1.7 \%)$ & $\chi^{2}=0.99$ \\
\hline & & & $p=0.3193$ \\
\hline \multirow[t]{2}{*}{ Diabetes } & $23(39.0 \%)$ & $23(38.3 \%)$ & $\chi^{2}=0.01$ \\
\hline & & & $p=0.9420$ \\
\hline \multirow[t]{2}{*}{ Arterial hypertension } & $41(69.5 \%)$ & $40(66.7 \%)$ & $\chi^{2}=0.11$ \\
\hline & & & $p=0.7410$ \\
\hline
\end{tabular}

TEA ICA - thromboendarterectomy of the internal carotid artery, $P C I$ - percutaneous coronary interventions, $C A B G$ - coronary artery bypass grafting, AAA-abdominal aortic aneurysm. 
Table VI. Duration of hospital stay in patients treated surgically and with endovascular angioplasty

\begin{tabular}{|lccc|}
\hline Duration of hospital stay & $\begin{array}{c}\text { Surgical treatment } \\
(n=59)\end{array}$ & $\begin{array}{c}\text { Endovascular angioplasty } \\
(n=60)\end{array}$ & $P$-value \\
\hline Mean \pm SD & $12.1 \pm 7.0$ & $3.2 \pm 2.4$ & $\begin{array}{c}Z=8.42 \\
p=0.0001\end{array}$ \\
\hline Range & $2.0-52.0$ & $2.0-15.0$ & \\
\hline Median & 12.0 & 2.0 & \\
\hline $95 \% \mathrm{Cl}$ & $10.3 ; 13.9$ & $2.5 ; 3.8$ & \\
\hline
\end{tabular}

common comorbidity in the endovascular group was arterial hypertension (40 subjects, $66.7 \%$ ) as well, but was followed by diabetes ( 23 subjects, $38.3 \%$ ), history of myocardial infarct (18 subjects, $30.0 \%)$ and ischaemic heart disease (16 subjects, $26.7 \%)$. Both ischaemic stroke $(p=0.0235)$ and a history of percutaneous coronary interventions $(p=0.0299)$ were significantly more frequent in patients treated with endovascular angioplasty. No statistically significant differences were observed for other parameters.

The analysis revealed statistically significant differences for the duration of hospital stay. The mean duration of hospital stay in the surgical and endovascular groups was $12.1 \pm 7.0$ (range: $2-52$ days, median: 12 days) and $3.2 \pm 2.4$ (range: $2-15$ days, median: 2 days), respectively (Table VI).

\section{Discussion}

The study group consisted of 119 patients with chronic lower limb ischaemia, who were treated either surgically or with endovascular angioplasty. The most common cause of chronic lower limb ischaemia is atherosclerosis [1-3]. The epidemiological studies indicate that the risk of developing atherosclerosis in the lower limb arteries increases with age and that men are affected more frequently than women, especially in younger age groups $[1,7,12]$. The mean age of studied subjects was 63 years, and there were twice as many men than women, which is consistent with epidemiological data. Most of the patients had elementary and vocational education, were either pensioners or recipients of disability benefits and residents of cities. The literature data suggest that subjects having a low level of education and a history of physical work constitute a high-risk population for atherosclerosis, which is attributed to their preferred life-style [1]. About $75 \%$ of our patients were married, which suggests additional support thanks to the participation and involvement of their relatives in the decision-making process concerning their medical care and therapy.

The analysed groups were homogeneous with regard to age, gender, education, marital status, place of residence, occupation and source of income.

The analysis of the patient subgroups (Table I) revealed differences in their clinical condition.
The endovascular group was more heterogeneous with regard to the severity of lower limb ischaemia. Stage II ischaemia was observed in 27 patients, stage III in 22, and stage IV in 11 . The surgical group consisted of patients with stage III and stage IV ischaemia only. Rest pain and foot/shin ulceration were significantly more frequent in the latter group. There was no difference between the analysed groups in terms of the duration of the disease symptoms (median: 4 years).

The general cardiovascular risk and the comorbidities have to be considered once the patient is qualified for surgical management of chronic lower limb ischaemia $[7,8]$. The conducted research was of an observational nature. It has been observed that more burdened patients (who have undergone surgical coronary interventions or experienced cerebral ischaemic stroke) were qualified for endovascular treatment.

There are many factors increasing the risk of atherosclerotic lower limb ischaemia, namely: smoking, diabetes, arterial hypertension, dyslipidaemia, increased blood viscosity and thrombophilic states, obesity and low physical activity $[1,2,8,12]$. The authors of the above-mentioned studies and others indicate that the most common risk factors among the studied patients were smoking, arterial hypertension, diabetes and overweight $[1,8]$.

Smoking is considered one of the most significant risk factors for cardiovascular diseases. Epidemiological studies have indicated a clear association between smoking and chronic lower limb ischaemia [9, 17-19].

In order to obtain the best possible results in the process of giving up smoking, most attention should be given to motivating the patient appropriately to attempt giving up smoking and to refrain from smoking as long as possible. It should be emphasized that motivation is a dynamic process and it can be either strengthened or maintained potentially with every patient [20].

Our own data indicate that significantly more current smokers were among patients treated with endovascular intervention, whereas significantly more ex-smokers were treated surgically. Smoking cessation was observed in approximately $50.8 \%$ of patients treated surgically. As smok- 
ing cessation is desirable, all the patients should be encouraged to do so [20]. Unfortunately, it is disturbing that despite being diagnosed with such a disease, a considerable number of patients still smoke at least 20 cigarettes a day. Sztuczka and Szewczyk [21] conducted a study using Nina Schneider's test to assess the motivation of the patients with lower limb atherosclerosis to stop smoking. Their results indicate that the motivation level to stop smoking was to a greater extent dependant on the influence of the work environment and ability to handle crisis situations than on the clinical stage of disease severity.

Diabetes and arterial hypertension are other important risk factors of atherosclerosis [1, 8, 12]. The above-mentioned diseases were the most common comorbidities in both groups. Many studies indicate that both diabetes and arterial hypertension are associated with the development of peripheral artery disease. The course of the disease is more rapid in patients with diabetes, and the amputation rate is 5-10 times higher than in non-diabetic patients [12].

The BMI was used to evaluate the stage of overweight or obesity in the study group. The obtained data revealed that the mean BMI in both the surgical $(26.1 \pm 4.7)$ and endovascular (27.7 \pm 6.0 ) groups indicated overweight. In daily practice one should aim at obtaining and maintaining predicted body mass in patients with chronic lower limb ischaemia. The reduction of body mass in overweight or obese patients may contribute to the improvement of claudication distance. The community nurses and general physicians working in primary healthcare should educate patients on the influence that overweight or obesity has on the development of chronic lower limb ischaemia. Dorobisz et al. [1] evaluated the incidence of lower limb atherosclerosis in the population of Opolian Silesia. The analysis of the atherosclerosis risk factors revealed that the population of obese patients was reduced in relation to the prevalence of obesity in Poland's adult population. It should be emphasised that such a result could have been influenced by the actions performed during prophylactic actions. The knowledge of the influence that the analysed factors have on the prevalence of chronic lower limb ischaemia is therefore of significance in the course of optimal planning of the therapeutic process in this patient group.

In conclusion, the clinical analysis of the patients with lower limb artery atherosclerosis indicate that the group treated surgically shows more advanced disease compared to the group of patients treated with endovascular angioplasty. The patients with more severe vascular disease are more willing to give up smoking; therefore more emphasis should be put on prophylaxis for patients treated with an endovascular procedure. The group of patients treated with endovascular angioplasty included significantly more subjects with a history of ischaemic stroke, surgical coronary interventions and current smokers.

\section{Conflict of interest}

The authors declare no conflict of interest.

\section{References}

1. Dorobisz A, Kucharski A, Sikorski A, Kowalik Z, Hobot J. Morbidity of lower limbs obliterating atherosclerosis in the population of Opole Region. Przegl Epidemiol 2005; 59: 933-44.

2. Aronow WS. Peripheral arterial disease of the lower extremities. Arch Med Sci 2012; 8: 375-88.

3. Sakaki S, Takahashi T, Matsumoto J, et al. Characteristics of physical activity in patients with critical limb ischemia. J Phys Ther Sci 2016; 28: 3454-7.

4. Zdrojowy K, Sapian-Raczkowska B, Adamiec R. Chronic lower limb ischemia - clinical symptom element of atherosclerosis - actual guideline. Pol Merkuriusz Lek 2010; 28: 163-71.

5. Varu VN, Hogg ME, Kibbe MR. Critical limb ischemia. J Vasc Surg 2010; 51: 230-41.

6. Dormandy JA, Rutherford RB. Management of peripheral arterial disease (PAD). TASC Working Group. TransAtlantic Inter-Society Consensus (TASC). J Vasc Surg 2000; 31: S1-296.

7. Rościszewski P, Koziarska-Rościszewska M. Niezdolność do pracy $u$ osób z niedokrwieniem kończyn dolnych [Polish]. Orzecznictwo Lekarskie 2009; 6: 48-66.

8. Fowkes FG, Rudan D, Rudan I, et al. Comparison of global estimates of prevalence and risk factors for peripheral artery disease in 2000 and 2010: a systematic review and analysis. Lancet 2013; 382: 1329-40.

9. Hirsch AT, Haskal ZJ, Hertzer NR, et al. ACC/AHA 2005. Practice Guidelines for the Management of Patients With Peripheral Arterial Disease (Lower Extremity, Renal, Mesenteric, and Abdominal Aortic): a collaborative report from the American Association for Vascular Surgery/Society for Vascular Surgery, Society for Cardiovascular Angiography and Interventions, Society for Vascular Medicine and Biology, Society of Interventional Radiology, and the ACC/AHA Task Force on Practice Guidelines (Writing Committee to Develop Guidelines for the Management of Patients With Peripheral Arterial Disease): endorsed by the American Association of Cardiovascular and Pulmonary Rehabilitation; National Heart, Lung, and Blood Institute; Society for Vascular Nursing; Trans-Atlantic Inter-Society Consensus; and Vascular Disease Foundation. Circulation 2006; 113: e463-654.

10. Weitz J, Byrne J, Clagett P, et al. Diagnosis and treatment of chronic arterial insufficiency of the lower extremities: a critical review. Circulation 1996; 94: 3026-7.

11. Dattilo PB, Casserly IP. Critical limb ischemia: endovascular strategies for limb salvage. Prog Cardiovasc Dis 2011; 54: 47-60.

12. Norgren L, Hiatt WR, Dormandy JA, et al. Konsensus dotyczący postępowania w chorobie tętnic obwodowych (TASC II). Acta Angiologica 2007; 13 Supl. D: 26-32; 39; 55-64. 
13. Heo $S$, Soukas $P$, Aronow HD. Is common femoral artery stenosis still a surgical disease? Interv Cardiol Clin 2017; 6: 181-7.

14. Chen DC, Singh GD, Armstrong EJ, Waldo SW, Laird JR, Amsterdam EA. Long-term comparative outcomes of patients with peripheral artery disease with and without concomitant coronary artery disease. Am J Cardiol 2017; 119: 1146-52.

15. Dalal PK, Prasad A. Contemporary outcomes of endovascular intervention for critical limb ischemia. Interv Cardiol Clin 2017; 6: 251-9.

16. Polskie zalecenia wewnątrznaczyniowego leczenia chorób tętnic obwodowych i aorty 2009. Chir Pol 2009; 1: 1-12.

17. Golec K, Szewczyk MT, Stodolska A, et al. Evaluation of perioperative standard of care among patients with peripheral arterial occlusive disease. Surg Vasc Nurs 2007; 75: 69-76.

18. Schanzer A, Conte MS. Critical limb ischemia. Curr Treat Options Cardiovasc Med 2010; 12: 214-29.

19. DeRubertis BG, Faries PL, McKinsey JF, et al. Shifting paradigms in the treatment of lower extremity vascular disease: a report of 1000 percutaneous interventions. Ann Sur 2007; 246: 415-22.

20. Suwała M, Drygas W, Gerstenkorn A. Eldery ex-smokers and their health status. Pol Merkuriusz Lek 2007; 22: 532-5.

21. Sztuczka E, Szewczyk MT. Assessment of motivation of patients with peripheral arterial disease to stop smoking based on Nina Schneider's test. Surg Vasc Nurs 2008; 1: 5-11. 